${ }^{3}$ A. L. Feild: Trans. Faraday Soc. (1925-1926) 21, pp. 255-267.

${ }^{*} \mathrm{H}$. Schenck: Physical Chemistry of Steelmaking. (English Translation). British Iron and Steel Research Assn., pp. 186 and 200 (1945).

${ }^{5} \mathrm{~J}$. Chipman: Trans. A.S.M. (1934) 22, pp. 384-446.

${ }^{B}$ C. H. Herty and G. R. Fitterer: Physical Chemistry of Steelmaking. Carnegie Inst. of Tech. and U. S. Bur. Mines, Coop Bull. 36 (1928). C. H. Herty, G. R. Fitterer, C. F. Christopher: Ibid. Tech. Paper 492 (1931).

${ }^{7} \mathrm{H}$. Schenck and O. Bruggemann: Archiv Eisenhüttenwesen (1935-1936) 9, pp. 543-553.

${ }^{8}$ F. Körber: Stahl und Eisen (1934) 15, pp. 535-543.

${ }^{9}$ F. Körber and W. Oelsen: Mitt. K.-W. Inst. Eisenforschung (1933) 15, pp. 271-309.

${ }^{10}$ L. S. Darken: Trans. AIME (1940) 140, pp. 204-221.

11 C. A. Zapffe and C. E. Sims: Trans. AIME (1943) 154, pp. 192-227.

${ }_{12}$ D. C. Hilty and W. Crafts: Trans. AIME (1950)

188, p. 425; Journal of Metals (February 1950).
${ }^{13}$ M. N. Dastur and J. Chipman: Trans. AIME (1949) 185, pp. 441-445; Journal of Metals (August 1949).

${ }^{14}$ N. A. Gokcen: Journal Amer. Chem. Soc. (1951) 73, p. 3789.

${ }^{15}$ M. N. Dastur and J. Chipman: Discussions, Faraday Soc. (1948) No. 4, p. 100.

${ }^{16}$ M. N. Dastur and N. A. Gokcen: Trans. AIME (1949) 185, p. 665; Journal of Metals (October 1949).

${ }^{17}$ C. F. Goodeve: Discussions, Faraday Soc. (1948) No. 4 , p. 9 .

${ }^{18}$ M. G. Fontana and J. Chipman: Trans. A.S.M. (1936) 24, p. 313.

${ }^{10} \mathrm{~J}$. Chipman and A. M. Samarin: Trans. AIME (1937) 125, p. 331.

${ }^{20}$ C. R. Taylor and J. Chipman: Trans. AIME (1943) 154, p. 228.

${ }^{21}$ C. Wagner: Journal of Chemical Physics (1951) 19, p. 626.

\title{
Technical Note Growth of Austenite in Cold-Rolled Tempered Martensite
}

\author{
by A. E. Nehrenberg
}

$I^{\mathrm{N}}$ N. an earlier publication ${ }^{1}$ it was shown that the shape assumed by a volume of growing austenite is inherited from the prior structure. The matrix grains of pearlitic microstructures are equiaxed, and austenite grows in an equiaxed manner in these prior structures. Martensite and bainite, on the other hand, have an acicular grain structure, and the austenite produced in such structures grows in an acicular manner.

In the discussion of this paper ${ }^{2}$ it was pointed out that in cold-rolled tempered martensite, austenite grows in an equiaxed, rather than an acicular manner. The results of an experiment carried out to arrive at an understanding of this behavior are illustrated by the micrographs.

Fig. 1 shows the acicular microstructure produced by heating tempered martensite to a temperature within the Ac1-Ac3 range, $1350^{\circ} \mathrm{F}$. When tempered martensite is cold rolled, then heated to the same temperature, the equiaxed structure shown in Fig. 2 is produced. A sample of cold-rolled tempered martensite heated at $1350^{\circ} \mathrm{F}$ just long enough for the formation of a small amount of austenite is shown by Fig. 3 to have an equiaxed (recrystallized) ferrite grain structure. The small particles of austenite which formed at $1350^{\circ} \mathrm{F}$ in the equiaxed ferrite matrix are likewise equiaxed.

Thus, the equiaxed growth of austenite in coldworked tempered martensite is not a contradiction of the principles described in the previous paper, for the growth pattern reflects the matrix grain structure existing at the time of austenite formation.

\section{References}

${ }^{1}$ A. E. Nehrenberg: The Growth of Austenite as Related to Prior Structure. Trans. AIME (1950) 188, pp. 162-174; Journal of Metals (January 1950).

${ }^{2}$ J. R. Vilella and R. A. Grange: Discussion of ref. 1. Trans. AIME (1950) 188, pp. 1378-1381; JoURNAL OF Metals (November 1950).

A. E. NEHRENBERG, Member AIME, is associated with the Metallurgical Dept., Crucible Steel Co. of America, Harrison, N. J. TN 101E. Manuscript, Nov. 15, 1951.
Figs. I to 3-Effect of cold rolling on growth pattern of austenite in tempered martensite. $\mathrm{X} 2000$.

Fig. 1-Tempered martensite heated $1 / 2 \mathrm{hr}$ at $1350^{\circ} \mathrm{F}$, quenched, and tempered $1 / 2 \mathrm{hr}$ at $600^{\circ} \mathrm{F}$.

Dark etching structure (tempered martensite) was a ustenite at time of was austenite at time of chloride-picral etch.

Fig. 2-Tempered martensite cold rolled 50 pct, then heat treated in the same manner as Fig. 1.

Etch same as Fig. 1.

Fig. 3-Tempered martensite cold rolled 50 pct and heated $2 \mathrm{~min}$ total time in lead at $1350^{\circ} \mathrm{F}$, quenched, and tempered $1 / 2 \mathrm{hr}$ at $600^{\circ} \mathrm{F}$. Nominal composition of
steel used was: 0.25 pet C, 1.3 pet Mn, 1.5 pet Si, 1.8 pet Ni, and 0.40 pet Mo. Etched in Allten's reagent.

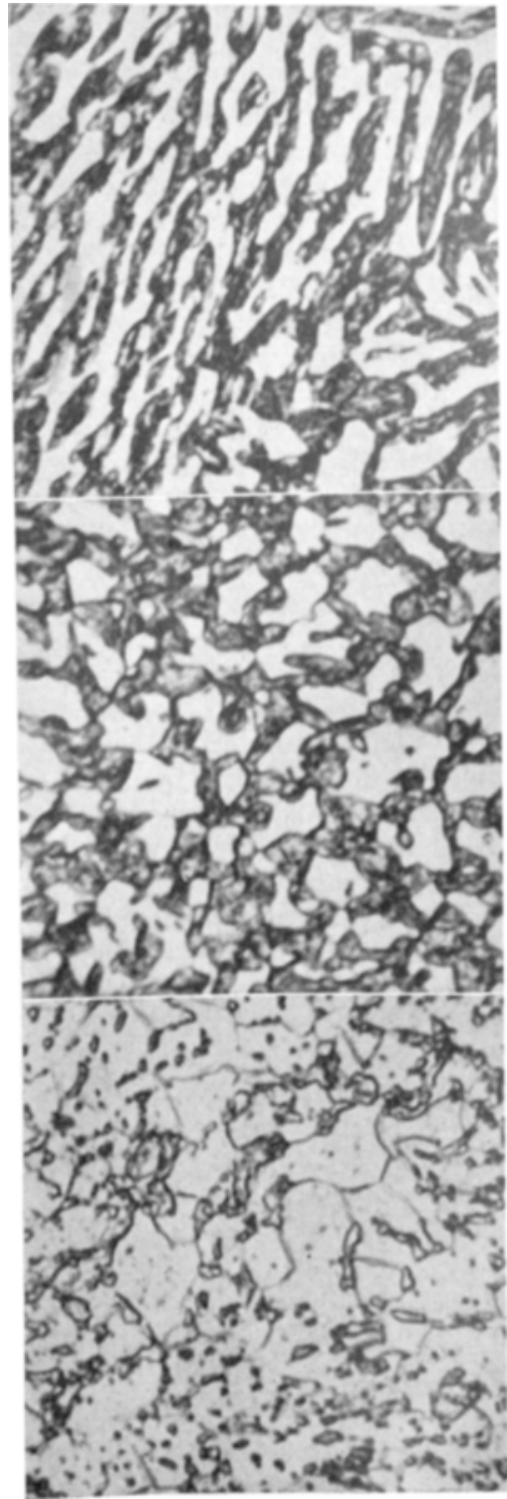

